\title{
PENGARUH PUPUK ORGANIK CAIR NASA DAN PUPUK KOMPOS TERHADAP PERTUMBUHAN BIBIT JERUK MANIS (Citrus aurantium).
}

\author{
Mario $^{1}$, Puji Astuti ${ }^{2}$, dan Akas Pinaringan Sujalu ${ }^{2}$ \\ ${ }^{1}$ Agroteknologi, Fakultas Pertanian, Universitas 17 Agustus 1945 Samarinda, Indonesia. \\ ${ }^{2}$ Dosen Fakultas Pertanian, Universitas 17 Agustus 1945 Samarinda 75124, Indonesia. \\ ${ }^{1}$ E-Mail: mario@untag-smd.ac.id \\ ${ }^{2}$ E-Mail: pujiastuti@untag-smd.ac.id
}

\begin{abstract}
ABSTRAK
Pengaruh Pupuk Organik Cair Nasa dan Pupuk Kompos Terhadap Pertumbuhan Bibit Jeruk Manis (Citrus aurantium). Tujuan penelitian untuk mengetahui pengaruh konsentrasi pupuk organik cair nasa dan pupuk kompos serta interaksinya terhadap pertumbuhan bibit jeruk manis, dan juga untuk mengetahui konsentrasi pupuk organik cair nasa dan dosis pupuk kompos yang tepat untuk pertumbuhan bibit jeruk manis (Citrus aurantium).

Penelitian menggunakan Rancangan Acak Lengkap (RAL), dalam percobaan faktorial 3 x 3, dengan 5 ulangan. Terdiri atas 2 faktor perlakuan. Faktor I adalah jenis pupuk organik cair Nasa (V), terdiri atas 3 taraf, yaitu : tanpa pupuk organik cair Nasa $\left(\mathrm{v}_{0}\right)$, konsentrasi pupuk organik cair Nasa 1 ml/l.air $\left(\mathrm{v}_{1}\right)$, dan konsentrasi pupuk organik cair Nasa $2 \mathrm{ml} / \mathrm{l}$.air $\left(\mathrm{v}_{2}\right)$. Faktor II adalah dosis pupuk kompos (K), terdiri atas 3 taraf, yaitu : dosis pupuk kompos 15 ton/ha setara $15 \mathrm{~g} /$ polibag $\left(\mathrm{k}_{1}\right)$, dosis pupuk kompos 30 ton/ha setara 30 $\mathrm{g} /$ polibag $\left(\mathrm{k}_{2}\right)$, dan dosis pupuk kompos 45 ton/ha setara $45 \mathrm{~g} /$ polibag $\left(\mathrm{k}_{3}\right)$.

Hasil penelitian menunjukkan bahwa perlakuan pupuk Nasa tidak berpengaruh nyata terhadap jumlah daun umur 90 hari setelah tanam. Berpengaruh nyata terhadap tinggi bibit umur 60 hari setelah tanam, jumlah daun umur 30 hari dan 60 hari setelah tanam dan diameter batang umur 30 hari dan 60 hari setelah tanam.

Interaksi perlakuan antara perlakuan pupuk Nasa dan pupuk kompos berpengaruh tidak nyata terhadap tinggi bibit umur 30 hari dan 60 hari setelah tanam, jumlah daun umur 30 hari, umur 60 hari dan umur 90 hari setelah tanam, diameter batang umur 30 hari dan umur 90 hari setelah tanam. Berpengaruh nyata terhadap diameter batang umur 60 hari setelah tanam. Berpengaruh sangat nyata terhadap diameter batang umur 60 hari setelah tanam.
\end{abstract}

Kata kunci : Jeruk manis, Pupuk kompos, Pupuk organic cair nasa.

\begin{abstract}
Effect of Organic Liquid Fertilizer and Compost Fertilizer on the Growth of Sweet Orange Seeds (Citrus aurantium). The purpose of this study was to determine the effect of the concentration of liquid liquid organic fertilizer and compost and its interactions on the growth of sweet orange seeds, and also to determine the concentration of liquid organic fertilizer in nasa and the appropriate dose of compost for the growth of sweet orange seeds (Citrus aurantium).

The study used a completely randomized design (CRD), in a factorial experiment of $3 \times 3$, with 5 replications. Consists of 2 treatment factors. Factor I is the type of liquid organic fertilizer Nasa (V), consisting of 3 levels, namely: without liquid organic fertilizer Nasa (v0), the concentration of liquid organic fertilizer Nasa $1 \mathrm{ml} /$ l.water ( $\mathrm{vl})$, and the concentration of liquid organic fertilizer Nasa $2 \mathrm{ml} / \mathrm{l}$. water (v2). Factor II is the dose of compost $(K)$, consisting of 3 levels, namely: the dose of compost 15 tons / ha equivalent to $15 \mathrm{~g} /$ polybag ( $k 1)$, the dose of compost 30 tons / ha equivalent to $30 \mathrm{~g} /$ polybag $(\mathrm{k} 2)$, and compost dose of 45 tons / ha is equivalent to $45 \mathrm{~g} /$ polybag (K3).

The results showed that the treatment of Nasa fertilizer did not significantly affect the number of leaves aged 90 days after planting. Significantly affected the height of the seedlings aged 60 days after planting, the number of leaves aged 30 days and 60 days after planting and the diameter of the stem age 30 days and 60 days after planting.
\end{abstract}


The interaction of treatment between the treatment of Nasa fertilizer and compost did not significantly influence the height of seedlings aged 30 days and 60 days after planting, the number of leaves aged 30 days, age 60 days and age 90 days after planting, stem diameter age 30 days and age 90 days after planting. Significantly affect the diameter of the stem age 60 days after planting. Very significant effect on stem diameter at 60 days after plantingces.

Key words : Compost fertilizer, Organic liquid fertilizer fertilizer, Sweet orange.

\section{PENDAHULUAN}

Jeruk merupakan buah yang digemari masyarakat dan memiliki prospek agribisnis yang dapat meningkatkan kesejahteraan petani jeruk di Indonesia. Jeruk dapat dikonsumsi dalam bentuk segar maupun olahan dengan kadar protein $0,5 \mathrm{~g}$, lemak $0,1 \mathrm{~g}$, vitamin C 500 - $1.000 \mathrm{~g}$ dan karbohidrat 7,20 g. Indonesia telah menjadikan jeruk menjadi produk industri seperti: minyak dari kulit dan biji jeruk, alkohol, gula tetes dan pektin dari buah jeruk yang terbuang. Minyak dari kulit jeruk dipakai untuk minyak wangi, sabun dan campuran kue (Wirakusumah, 1999).

Dilihat dari prospek budidaya jeruk di Indonesia khususnya Kalimantan Timur belum cukup baik, sehingga saat ini harus terus dibudidayakan karena mempunyai nilai komersial yang tinggi. Buah jeruk merupakan salah satu jenis buah yang paling banyak di gemari oleh masyarakat. Untuk mempertahankan tanaman jeruk agar tetap selalu ada serta sebagai plasma nuftah di masa yang akan datang perlunya pembibitan yang lebih banyak baik itu dari generatif (berasal dari biji) dan vegetatif (berasal dari okulasi maupun sambung pucuk). Dimana kita lihat bahwa luasnya lahan untuk Kalimantan Timur masih mampu untuk menanam jenis tanaman buahbuahan khususnya jeruk. Satu diantara jenis jeruk sebagai varitas unggul nasional yang telah resmi dilepas pemerintah adalah jeruk manis keprok.

Jeruk dimanfaatkan sebagai obat tradisional, seperti penurun panas, pereda nyeri dan untuk radang mata. Produk jeruk Indonesia berfluktuasi, hal ini dapat dilihat dari produksi dan luas areal dari tahun 2009 luas areal 350 ha dan menurun menjadi 150 ha pada tahun 2012, sedangkan produksi jeruk pada tahun yang sama menurun dari 437.149 ton menjadi 293.460 ton/tahun. Oleh karena itu untuk mencapai sasaran tingkat konsumsi sebesar 3,26 $\mathrm{kg}$ perkapita per tahun diperlukan buah jeruk sebanyak 745.676 ton (Endarto dan Martini, 2016).

Dari latar belakang tersebut sehingga perlu dilakukan penelitian yang berjudul : " Pengaruh Pupuk Organik Cair Nasa dan Pupuk Kompos Terhadap Pertumbuhan Bibit Jeruk Manis (Citrus aurantium) ". Tujuan penelitian adalah: Untuk mengetahui pengaruh konsentrasi pupuk organik cair Nasa dan pupuk kompos serta interaksinya terhadap pertumbuhan bibit jeruk manis (Citrus aurantium). Untuk mengetahui konsentrasi pupuk organik cair Nasa dan dosis pupuk kompos yang tepat untuk pertumbuhan bibit jeruk manis (Citrus aurantium).

\section{METODA PENELITIAN}

\subsection{Tempat dan Waktu}

Lokasi penelitian di Desa Bumi Rapak, Kecamatan Kaubun, Kabupaten Kutai Timur, Provinsi Kalimantan Timur. Pada bulan Maret-Juni 2015.

\subsection{Bahan dan Alat}

Bahan-bahan yang digunakan dalam penelitian ini adalah : bibit jeruk manis varietas keprok siam, pupuk organik cair Nasa, pupuk kompos, polibag ukuran $15 \mathrm{~cm}$ x $30 \mathrm{~cm}$, 
tanah, Furadan 3G, Fungisida Anfush, insektisida Curacron. Sedangkan alat-alat yang digunakan dalam penelitian adalah : alat tulis menulis, artco, cangkul, paranet, kayu balok, ayakan, kamera, computer, sprayer, stapler, meteran, jangka sorong, pisau, plastik dan gunting.

\subsection{Rancangan Penelitian}

Penelitian ini dilaksanakan dengan menggunakan Rancangan Acak Lengkap (RAL) dengan analisis faktorial 3 x 3 dengan jumlah ulangan sebanyak 5 kali. Faktor perlakuan dalam penelitian ini adalah

Perlakuan Konsentrasi Pupuk Organik Cair Nasa (V), terdiri atas 3 taraf, yaitu:

$$
\begin{array}{ll}
\mathrm{v}_{0} & =\text { tanpa POC Nasa } \\
\mathrm{v}_{1} & =1 \mathrm{ml} \mathrm{l}^{-1} \text { POC Nasa } \\
\mathrm{v}_{2} & =2 \mathrm{ml} \mathrm{l}^{-1} \text { POC Nasa }
\end{array}
$$

Perlakuan Pupuk Kompos (K) terdiri atas 3 taraf, yaitu:

$\mathrm{k}_{1} \quad=$ dosis pupuk kompos 15 ton $\mathrm{ha}^{-1}$ setara $15 \mathrm{~g}$ polibag ${ }^{-1}$

$\mathrm{k}_{2}=$ dosis pupuk kompos 30 ton $\mathrm{ha}^{-1}$ setara $30 \mathrm{~g}$ polibag ${ }^{-1}$

$\mathrm{k}_{3}=$ dosis pupuk kompos 45 ton $\mathrm{ha}^{-1}$ setara $45 \mathrm{~g}_{\text {polibag }}{ }^{-1}$

Kombinasi perlakuan Konsentrasi pupuk POC Nasa dan pupuk kompos adalah $\mathrm{v}_{0} \mathrm{k}_{1} \quad \mathrm{v}_{1} \mathrm{k}_{1} \quad \mathrm{v}_{2} \mathrm{k}_{1}$ $\mathrm{v}_{0} \mathrm{k}_{2} \quad \mathrm{v}_{1} \mathrm{k}_{2} \quad \mathrm{v}_{2} \mathrm{k}_{2}$ $\mathrm{v}_{0} \mathrm{k}_{2} \quad \mathrm{v}_{1} \mathrm{k}_{3} \quad \mathrm{v}_{2} \mathrm{k}_{3}$

Terdapat kombinasi perlakuan pupuk organik cair Nasa dan pupuk kompos serta ulangan sebanyak 5 kali, maka menjadi 3 × 3 × $5=45$ unit perlakuan.

\subsection{Pelaksanaan Penelitian}

Persiapan Media Tanam: Media yang digunakan untuk penelitian merupakan tanah top soil yang diambil di sekitar lokasi penelitian. Tanah top soial tersebut dibersihkan dari gulma dan kotoran lainnya, kemudian diratakan dengan cangkul. Kemudian tanah tersebut dimasukkan ke dalam polibag ukuran $15 \mathrm{~cm}$ x 30 $\mathrm{cm}$ dengan berat tanah $\pm 2 \mathrm{~kg}$, kemudian diletakkan di lokasi penelitian yang datar dan telah dibersihkan dari gulma, kemudian di beri label sesuai perlakuan. Peletakan polibag disusun berdasarkan pengacakan menggunakan undian. Jarak antar polibag $30 \mathrm{~cm}$.

Penanaman: Bibit jeruk manis umur 2 minggu setelah okulasi di tanam dalam media yang telah disiapkan, dan di tanam 1 bibit per polibag.

Pemupukan: Perlakuan pupuk kompos diberikan 2 minggu sebelum tanam dengan dosis sesuai perlakuan. Pupuk POC Nasa diberikan 1 minggu setelah tanam, dan pemberian konsentrasi POC Nasa dengan cara disemprotkan pada bagian daun pada waktu pagi hari pukul 07.00 wita. Selanjutnya POC Nasa diberikan dengan interval 1 minggu sekali sampai umur 3 bulan.

Pemeliharaaan Bibit: Penyiraman, Penyiraman dilakukan secukupnya, yaitu 2 kali sehari (pagi hari dan sore hari).

Penyiangan: Penyiangan gulma atau tumbuhan pengganggu baik di bedengan dilakukan secara periodik. Pencabutan gulma dilakukan secara hati-hati agar tidak merusak perakaran.

Penyulaman: Penyulaman dilakukan apabila ada bibit yang mati dengan menggunakan bibit cadangan.

Pengendalian hama dan penyakit: Pengendalian hama dan penyakit dengan menyemprotkan Anfush dengan konsentrasi 2,5 gram/liter air dan curacron dengan konsentrasi 2 $\mathrm{ml} /$ liter air seminggu sekali.

\subsection{Analisis Data}


Untuk mengetahui pengaruh perlakuan pupuk organik cair Nasa dan pupuk kompos serta interaksinya terhadap pertumbuhan bibit jeruk manis, maka dilakukan dengan menganalisis data hasil pengamatan dengan sidik ragam. Model sidik ragam yang digunakan adalah menurut Steel dan Torrie (1994).

Apabila hasil sidik ragam tidak berpengaruh nyata (F.hitung $\leq$ F.tabel 5\%), maka tidak dilakukan uji

$$
\text { BNT 5\% }=\mathbf{t} \text { tabel } x \sqrt{2 K T G a l a t ~} / \mathbf{r}
$$

Keterangan :

$\mathrm{T}$ tabel $=$ nilai t tabel $(\alpha=5 \%$; nilai derajat bebas galat $)$

KT Galat $=$ Kuadrat tengah galat

$\mathrm{r} \quad=$ jumlah ulangan

\section{HASIL PENELITIAN DAN PEMBAHASAN}

\subsection{Tinggi Bibit Umur 30 Hari Setelah Tanam (cm)}

lanjut, tetapi bila hasil sidik ragam berpengaruh nyata (F.hitung $\geq$ F.tabel $5 \%$ ) atau berpengaruh sangat nyata (F.hitung $\geq$ F.tabel 1\%), maka dilakukan uji lanjut dengan uji Beda Nyata Terkecil (BNT) untuk membandingkan dua rata-rata perlakuan.

Rumus yang digunakan untuk uji lanjut dengan uji BNT pada taraf $5 \%$ menurut Hanafiah (2006) adalah :

\begin{abstract}
Hasil sidik ragam menunjukkan bahwa perlakuan pupuk organik cair Nasa dan pupuk kompos berpengaruh sangat nyata, sedangkan interaksinya tidak berpengaruh nyata terhadap tinggi bibit umur 30 hari setelah tanam. Data hasil penelitian disajikan pada Tabel 1 .
\end{abstract}

Tabel 1. Rekapitulasi Data Penelitian Pengaruh Pupuk Organik Cair Nasa dan Pupuk Kompos Terhadap Pertumbuhan Bibit Jeruk Manis (Citrus aurantium)

\begin{tabular}{|c|c|c|c|c|c|c|c|c|c|}
\hline \multirow{2}{*}{$\begin{array}{l}\text { Faktor } \\
\text { Perlakuan }\end{array}$} & \multicolumn{3}{|c|}{ Tinggi Bibit $(\mathrm{cm})$} & \multicolumn{3}{|c|}{ Jumlah Daun (helai) } & \multicolumn{3}{|c|}{ Diameter Batang $(\mathrm{cm})$} \\
\hline & $30 \mathrm{HST}$ & $60 \mathrm{HST}$ & $90 \mathrm{HST}$ & $30 \mathrm{HST}$ & $60 \mathrm{HST}$ & $90 \mathrm{HST}$ & $30 \mathrm{HST}$ & $60 \mathrm{HST}$ & $\begin{array}{c}90 \\
\text { HST }\end{array}$ \\
\hline $\begin{array}{l}\text { POC Nasa } \\
\text { (V) } \\
\text { Sidik Ragam }\end{array}$ & $* *$ & $*$ & $* *$ & $*$ & $*$ & $\operatorname{tn}$ & $*$ & $*$ & $* *$ \\
\hline $\begin{array}{l}0 \mathrm{ml} / \mathrm{l} \text {.air }\left(\mathrm{v}_{0}\right) \\
1 \mathrm{ml} / \mathrm{l} \text {.air }\left(\mathrm{v}_{1}\right) \\
2 \mathrm{ml} / \mathrm{l} \text {.air }\left(\mathrm{v}_{2}\right)\end{array}$ & $\begin{array}{l}13,45 \mathrm{~b} \\
13,49 \mathrm{~b} \\
14,11 \mathrm{a}\end{array}$ & $\begin{array}{l}22,00 \mathrm{~b} \\
23,76 \mathrm{a} \\
23,80 \mathrm{a}\end{array}$ & $\begin{array}{l}28,33 \mathrm{c} \\
30,00 \mathrm{~b} \\
31,87 \mathrm{a}\end{array}$ & $\begin{array}{l}6,64 \mathrm{~b} \\
6,67 \mathrm{~b} \\
7,00 \mathrm{a}\end{array}$ & $\begin{array}{l}10,59 \mathrm{~b} \\
10,63 \mathrm{~b} \\
11,00 \mathrm{a}\end{array}$ & $\begin{array}{l}16,59 \\
16,64 \\
16,87\end{array}$ & $\begin{array}{l}0,38 \mathrm{~b} \\
0,38 \mathrm{~b} \\
0,39 \mathrm{a}\end{array}$ & $\begin{array}{l}0,59 \mathrm{c} \\
0,61 \mathrm{~b} \\
0,65 \mathrm{a}\end{array}$ & $\begin{array}{l}0,91 \mathrm{c} \\
0,95 \mathrm{~b} \\
1,02 \mathrm{a}\end{array}$ \\
\hline $\begin{array}{l}\text { Pupuk } \\
\text { Kompos (K) } \\
\text { Sidik Ragam }\end{array}$ & $* *$ & $* *$ & $* *$ & $* *$ & $* *$ & $* *$ & $* *$ & $*$ & $*$ \\
\hline $\begin{array}{l}15 \text { ton/ha } \\
\left(\mathrm{k}_{1}\right) \\
30 \text { ton/ha }\end{array}$ & $13,17 \mathrm{c}$ & $22,57 \mathrm{~b}$ & $27,60 \mathrm{c}$ & $6,29 \mathrm{~b}$ & $10,22 \mathrm{c}$ & $16,15 \mathrm{~b}$ & $0,38 \mathrm{~b}$ & $0,59 \mathrm{c}$ & $0,93 \mathrm{~b}$ \\
\hline $\begin{array}{l}\left(\mathrm{k}_{2}\right) \\
45 \text { ton/ha } \\
\left(\mathrm{k}_{3}\right)\end{array}$ & $13,54 \mathrm{~b}$ & $24,20 \mathrm{a}$ & $29,47 \mathrm{~b}$ & $6,57 \mathrm{~b}$ & $10,55 \mathrm{~b}$ & $16,48 \mathrm{~b}$ & $0,38 \mathrm{~b}$ & $0,62 \mathrm{~b}$ & $\begin{array}{l}0,95 \mathrm{~b} \\
0,99 \mathrm{a}\end{array}$ \\
\hline $\begin{array}{l}\text { Interaksi } \\
\text { (VxK) } \\
\text { Sidik Ragam }\end{array}$ & tn & tn & $* *$ & tn & tn & tn & tn & $*$ & tn \\
\hline $\mathrm{v}_{0} \mathrm{k}_{1}$ & 13,00 & 20,40 & $26,20 \mathrm{f}$ & 6,14 & 10,06 & 16,06 & 0,37 & $0,58 \mathrm{~d}$ & 0,89 \\
\hline $\mathrm{v}_{0} \mathrm{k}_{2}$ & 13,34 & 22,80 & $28,00 \mathrm{de}$ & 6,50 & 10,36 & 16,36 & 0,38 & $0,59 \mathrm{~cd}$ & 0,90 \\
\hline $\mathrm{v}_{0} \mathrm{k}_{3}$ & 14,00 & 22,80 & $30,80 \mathrm{~b}$ & 7,28 & 11,36 & 17,36 & 0,39 & $0,61 \mathrm{c}$ & 0,94 \\
\hline $\mathrm{v}_{1} \mathrm{k}_{1}$ & 13,06 & 22,70 & $27,40 \mathrm{e}$ & 6,26 & 10,12 & 16,12 & 0,37 & $0,59 \mathrm{~cd}$ & 0,93 \\
\hline $\mathrm{v}_{1} \mathrm{k}_{2}$ & 13,40 & 23,78 & $28,60 \mathrm{~cd}$ & 6,42 & 10,50 & 16,50 & 0,38 & $0,61 \mathrm{c}$ & 0,95 \\
\hline $\mathrm{v}_{1} \mathrm{k}_{3}$ & 14,00 & 24,80 & $34,00 \mathrm{a}$ & 7,32 & 11,28 & 17,29 & 0,40 & $0,63 \mathrm{~b}$ & 0,96 \\
\hline
\end{tabular}




\begin{tabular}{llllllllll}
$\mathrm{v}_{2} \mathrm{k}_{1}$ & 13,44 & 22,60 & $29,20 \mathrm{c}$ & 6,48 & 10,48 & 16,28 & 0,39 & $0,61 \mathrm{c}$ & 0,98 \\
$\mathrm{v}_{2} \mathrm{k}_{2}$ & 13,88 & 23,80 & $31,80 \mathrm{~b}$ & 6,78 & 10,78 & 16,58 & 0,39 & $0,65 \mathrm{~b}$ & 1,00 \\
$\mathrm{v}_{2} \mathrm{k}_{3}$ & 15,00 & 25,00 & $34,60 \mathrm{a}$ & 7,74 & 11,74 & 17,75 & 0,41 & $0,69 \mathrm{a}$ & 1,08 \\
\hline
\end{tabular}

Keterangan :

HST : Hari Setelah Tanam

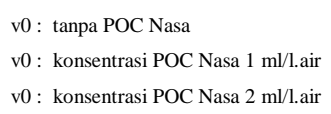

Hasi uji BNT taraf 5\% pada data penelitian tinggi bibit umur 30 hari setelah tanam pada perlakuan pupuk organik cair Nasa (V) menunjukkan bahwa perlakuan $v_{2}$ berbeda nyata dengan perlakuan $\mathrm{v}_{1}$ dan $\mathrm{v}_{0}$. Perlakuan $\mathrm{v}_{1}$ tidak berbeda nyata dengan perlakuan $\mathrm{v}_{0}$. Bibit tertinggi terdapat pada perlakuan $\mathrm{v}_{3}$ (konsentrasi pupuk organik cair Nasa 2 $\mathrm{ml} / \mathrm{l}$.air), yaitu $14,11 \mathrm{~cm}$, sedangkan yang terendah terdapat pada perlakuan $\mathrm{v}_{0}$ (tanpa pupuk Nasa), yaitu $13,45 \mathrm{~cm}$.

Hasi uji BNT taraf 5\% pada data penelitian tinggi bibit umur 30 hari setelah tanam pada perlakuan pupuk kompos (K) menunjukkan bahwa perlakuan $\mathrm{k}_{3}, \mathrm{k}_{2}$ dan $\mathrm{k}_{1}$, satu sama lainnya saling berbeda nyata. Bibit tertinggi terdapat pada perlakuan $\mathrm{k}_{3}$ (dosis pupuk kompos 45 ton/ha), yaitu $14,00 \mathrm{~cm}$, sedangkan yang terendah terdapat pada perlakuan $\mathrm{k}_{1}$ (dosis pupuk pupuk kompos 15 ton/ha), yaitu $13,17 \mathrm{~cm}$.

\subsection{Tinggi Bibit Umur 60 Hari Setelah Tanam (cm)}

Hasil sidik ragam menunjukkan bahwa perlakuan pupuk organik cair Nasa berpengaruh nyata, perlakuan pupuk kompos berpengaruh sangat nyata, sedangkan interaksinya tidak berpengaruh nyata terhadap tinggi bibit umur 60 hari setelah tanam.

Hasi uji BNT taraf 5\% pada data penelitian tinggi bibit umur 60 hari setelah tanam pada perlakuan pupuk organik cair Nasa (V) menunjukkan bahwa perlakuan $\mathrm{v}_{2}$ tidak berbeda nyata dengan perlakuan $\mathrm{v}_{1}$, tetapi berbeda nyata dengan perlakuan $\mathrm{v}_{0}$. Perlakuan $\mathrm{v}_{1}$

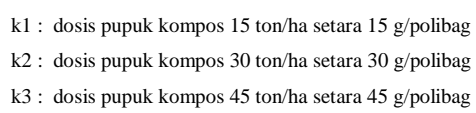

berbeda nyata dengan perlakuan $\mathrm{v}_{0}$. Bibit tertinggi terdapat pada perlakuan $\mathrm{v}_{2}$ (konsentrasi pupuk organik cair Nasa 2 $\mathrm{ml} / \mathrm{l}$.air), yaitu $23,80 \mathrm{~cm}$, sedangkan yang terendah terdapat pada perlakuan $\mathrm{v}_{0}$ (tanpa pupuk Nasa), yaitu $22,00 \mathrm{~cm}$.

Hasi uji BNT taraf $5 \%$ pada data penelitian tinggi bibit umur 60 hari setelah tanam pada perlakuan pupuk kompos (K) menunjukkan bahwa perlakuan $\mathrm{k}_{3}$ tidak berbeda nyata dengan perlakuan $\mathrm{k}_{2}$, tetapi berbeda nyata dengan perlakuan $\mathrm{k}_{1}$. Perlakuan $\mathrm{k}_{2}$ berbeda nyata dengan perlakuan $\mathrm{k}_{1}$. Bibit tertinggi terdapat pada perlakuan $\mathrm{k}_{3}$ (dosis pupuk kompos 45 ton/ha), yaitu $24,20 \mathrm{~cm}$, sedangkan yang terendah terdapat pada perlakuan $\mathrm{k}_{1}$ (dosis pupuk pupuk kompos 15 ton/ha), yaitu $22,57 \mathrm{~cm}$.

\subsection{Tinggi Bibit Umur 90 Hari Setelah Tanam (cm)}

Hasil sidik ragam menunjukkan bahwa perlakuan pupuk Nasa dan pupuk kompos serta interaksinya berpengaruh sangat nyata terhadap tinggi bibit umur 90 hari setelah tanam.

Hasi uji BNT taraf $5 \%$ pada data penelitian tinggi bibit umur 90 hari setelah tanam pada perlakuan pupuk organik cair Nasa (V) menunjukkan bahwa perlakuan $\mathrm{v}_{2}, \mathrm{v}_{1}$ dan $\mathrm{v}_{0}$ satu sama lainnya saling berbeda nyata. Bibit tertinggi terdapat pada perlakuan $\mathrm{v}_{2}$ (konsentrasi pupuk Nasa $2 \mathrm{ml} / \mathrm{l}$.air), yaitu $31,87 \mathrm{~cm}$, sedangkan yang terendah terdapat pada perlakuan $\mathrm{v}_{0}$ (tanpa pupuk Nasa), yaitu $28,33 \mathrm{~cm}$.

Hasi uji BNT taraf $5 \%$ pada data penelitian tinggi bibit umur 90 hari 
setelah tanam pada perlakuan pupuk kompos (K) menunjukkan bahwa perlakuan $\mathrm{k}_{3}, \mathrm{k}_{2}$ dan $\mathrm{k}_{1}$ satu sama lainnya saling berbeda nyata. Bibit tertinggi terdapat pada perlakuan $\mathrm{k}_{3}$ (dosis pupuk kompos 45 ton/ha), yaitu $33,13 \mathrm{~cm}$, sedangkan yang terendah terdapat pada perlakuan $\mathrm{k}_{1}$ (dosis pupuk pupuk kompos 15 ton/ha), yaitu $27,60 \mathrm{~cm}$.

Hasil uji BNT taraf $5 \%$ terhadap tinggi bibit umur 90 hari setelah tanam pada interaksi perlakuan pupuk organik cair Nasa dan pupuk kompos ( $\mathrm{VxK}$ ) menunjukkan bahwa perlakuan $\mathrm{v}_{2} \mathrm{k}_{3}$ dan $\mathrm{v}_{1} \mathrm{k}_{3}$ berbedanyata dengan perlakuan $\mathrm{v}_{2} \mathrm{k}_{2}$, $\mathrm{v}_{0} \mathrm{k}_{3}, \mathrm{v}_{2} \mathrm{k}_{1}, \mathrm{v}_{1} \mathrm{k}_{2}, \mathrm{v}_{0} \mathrm{k}_{2}, \mathrm{v}_{1} \mathrm{k}_{1}$ dan $\mathrm{v}_{0} \mathrm{k}_{1}$. Perlakuan $\mathrm{v}_{2} \mathrm{k}_{2}$ dan $\mathrm{v}_{0} \mathrm{k}_{3}$ berbeda nyata dengan perlakuan $\mathrm{v}_{2} \mathrm{k}_{1}, \mathrm{v}_{1} \mathrm{k}_{2}, \mathrm{v}_{0} \mathrm{k}_{2}, \mathrm{v}_{1} \mathrm{k}_{1}$ dan $\mathrm{v}_{0} \mathrm{k}_{1}$. Perlakuan $\mathrm{v}_{2} \mathrm{k}_{1}$ tidak berbeda nyata dengan perlakuan $\mathrm{v}_{1} \mathrm{k}_{2}$, tetapi berbeda nyata dengan perlakuan $\mathrm{v}_{0} \mathrm{k}_{2}$, $\mathrm{v}_{1} \mathrm{k}_{1}$ dan $\mathrm{v}_{0} \mathrm{k}_{1}$. Perlakuan $\mathrm{v}_{1} \mathrm{k}_{2}$ tidak berbeda nyata dengan perlakuan $\mathrm{v}_{0} \mathrm{k}_{2}$, tetapi berbeda nyata dengan perlakuan $\mathrm{v}_{1} \mathrm{k}_{1}$ dan $\mathrm{v}_{0} \mathrm{k}_{1}$. Perlakuan $\mathrm{v}_{0} \mathrm{k}_{2}$ tidak berbeda nyata dengan perlakuan $\mathrm{v}_{1} \mathrm{k}_{1}$, tetapi berbeda nyata dengan perlakuan $\mathrm{v}_{0} \mathrm{k}_{1}$. Perlakuan $\mathrm{v}_{1} \mathrm{k}_{1}$ berbeda nyata dengan perlakuan $\mathrm{v}_{0} \mathrm{k}_{1}$.

\subsection{Jumlah Daun Umur 30 Hari Setelah Tanam (helai)}

Hasil sidik ragam menunjukkan bahwa perlakuan pupuk organik cair Nasa berpengaruh nyata, perlakuan pupuk kompos berpengaruh sangat nyata, sedangkan interaksinya tidak berpengaruh nyata terhadap jumlah daun umur 30 hari setelah tanam.

Hasi uji BNT taraf 5\% pada data penelitian jumlah daun bibit umur 30 hari setelah tanam pada perlakuan pupuk organik cair Nasa (V) menunjukkan bahwa perlakuan $\mathrm{v}_{2}$ berbeda nyata dengan perlakuan $\mathrm{v}_{1}$ dan $\mathrm{v}_{0}$. Perlakuan $\mathrm{v}_{1}$ tidak berbeda nyata dengan perlakuan $\mathrm{v}_{0}$. Jumlah daun terbanyak terdapat pada perlakuan $\mathrm{v}_{2}$ (konsentrasi pupuk pupuk organik cair Nasa 2 ml/lair), yaitu 7,00 helai, sedangkan yang paling sedikit terdapat pada perlakuan $\mathrm{v}_{0}$ (tanpa pupuk Nasa), yaitu 6,64 helai.

Hasi uji BNT taraf $5 \%$ pada data penelitian jumlah daun bibit umur 30 hari setelah tanam pada perlakuan pupuk kompos (K) menunjukkan bahwa perlakuan $\mathrm{k}_{3}$ berbeda nyata dengan perlakuan $\mathrm{k}_{2}$ dan $\mathrm{k}_{1}$. Perlakuan $\mathrm{k}_{2}$ tidak berbeda nyata dengan perlakuan $\mathrm{k}_{1}$. Jumlah daun terbanyak terdapat pada perlakuan $\mathrm{k}_{3}$ (dosis pupuk kompos 45 ton/ha), yaitu 7,45 helai, sedangkan yang paling sedikit terdapat pada perlakuan $\mathrm{k}_{1}$ (dosis pupuk kompos 15 ton/ha), yaitu 6,29 helai.

\subsection{Jumlah Daun Umur 60 Hari Setelah Tanam $(\mathrm{cm})$}

Hasil sidik ragam menunjukkan bahwa perlakuan pupuk organik cair Nasa berpengaruh nyata, perlakuan pupuk kompos berpengaruh sangat nyata, sedangkan interaksinya tidak berpengaruh nyata terhadap jumlah daun umur 60 hari setelah tanam.

Hasi uji BNT taraf 5\% pada data penelitian jumlah daun bibit umur 60 hari setelah tanam pada perlakuan pupuk organik cair Nasa (V) menunjukkan bahwa perlakuan $\mathrm{v}_{2}$ berbeda nyata dengan perlakuan $\mathrm{v}_{1}$ dan $\mathrm{v}_{0}$. Perlakuan $\mathrm{v}_{1}$ tidak berbeda nyata dengan perlakuan $\mathrm{v}_{0}$. Jumlah daun terbanyak terdapat pada perlakuan $\mathrm{v}_{2}$ (konsentrasi pupuk organik cair Nasa 2 ml/l.air), yaitu 11,00 helai, sedangkan yang paling sedikit terdapat pada perlakuan $\mathrm{v}_{0}$ (tanpa pupuk Nasa), yaitu 10,59 helai.

Hasi uji BNT taraf 5\% pada data penelitian jumlah daun bibit umur 30 hari setelah tanam pada perlakuan pupuk kompos (K) menunjukkan bahwa perlakuan $\mathrm{k}_{3}, \mathrm{k}_{2}$ dan $\mathrm{k}_{1}$ satu sama lainnya saling berbeda nyata. Jumlah daun terbanyak terdapat pada perlakuan $\mathrm{k}_{3}$ (dosis pupuk kompos 45 ton/ha), yaitu 
11,46 helai, sedangkan yang paling sedikit terdapat pada perlakuan $\mathrm{k}_{1}$ (dosis pupuk kompos 15 ton/ha), yaitu 10,22 helai.

\subsection{Jumlah Daun Umur 90 Hari Setelah Tanam (helai)}

Hasil sidik ragam menunjukkan bahwa perlakuan pupuk kompos berpengaruh sangat nyata, sedangkan perlakuan pupuk organik cair Nasa dan interaksinya tidak berpengaruh nyata terhadap jumlah daun umur 90 hari setelah tanam.

Hasi uji BNT taraf 5\% pada data penelitian jumlah daun bibit umur 90 hari setelah tanam pada perlakuan pupuk kompos (K) menunjukkan bahwa perlakuan $\mathrm{k}_{3}$ berbeda nyata dengan perlakuan $\mathrm{k}_{2}$ dan $\mathrm{k}_{1}$. Perlakuan $\mathrm{k}_{2}$ tidak berbeda nyata dengan perlakuan $\mathrm{k}_{1}$. Jumlah daun terbanyak terdapat pada perlakuan $\mathrm{k}_{3}$ (dosis pupuk kompos 45 ton/ha), yaitu 17,47 helai, sedangkan yang paling sedikit terdapat pada perlakuan $\mathrm{k}_{1}$ (dosis pupuk kompos 15 ton/ha), yaitu 16,15 helai.

\subsection{Diameter Batang Umur 30 Hari Setelah Tanam $(\mathrm{cm})$}

Hasil sidik ragam menunjukkan bahwa perlakuan pupuk organik cair Nasa berpengaruh nyata, perlakuan pupuk kompos berpengaruh sangat nyata, sedangkan interaksinya tidak berpengaruh nyata terhadap diameter batang umur 30 hari setelah tanam.

Hasi uji BNT taraf $5 \%$ pada data penelitian diameter batang umur 30 hari setelah tanam pada perlakuan pupuk organik cair Nasa (V) menunjukkan bahwa perlakuan $\mathrm{v}_{2}$ berbeda nyata dengan perlakuan $\mathrm{v}_{1}$ dan $\mathrm{v}_{0}$. Perlakuan $\mathrm{v}_{1}$ tidak berbeda nyata dengan perlakuan $\mathrm{v}_{0}$. Diameter batang terbesar terdapat pada perlakuan $\mathrm{v}_{2}$ (konsentrasi pupuk organik cair Nasa $2 \mathrm{ml} / \mathrm{l}$.air), yaitu $0,39 \mathrm{~cm}$, sedangkan diameter batang terkecil terdapat pada perlakuan $\mathrm{v}_{0}$ (tanpa pupuk Nasa), yaitu $0,38 \mathrm{~cm}$.

Hasi uji BNT taraf $5 \%$ pada data penelitian diameter batang umur 30 hari setelah tanam pada perlakuan pupuk kompos (K) menunjukkan bahwa perlakuan $\mathrm{k}_{3}$ berbeda nyata dengan perlakuan $\mathrm{k}_{2}$ dan $\mathrm{k}_{1}$. Perlakuan $\mathrm{k}_{2}$ tidak berbeda nyata dengan perlakuan $\mathrm{k}_{1}$. Diameter batang terbesar terdapat pada perlakuan $\mathrm{k}_{3}$ (dosis pupuk kompos 45 ton/ha), yaitu $0,40 \mathrm{~cm}$, sedangkan diameter paling kecil terdapat pada perlakuan $\mathrm{k}_{1}$ (dosis pupuk kompos 15 ton/ha), yaitu $0,38 \mathrm{~cm}$.

\subsection{Diameter Batang Umur 60 Hari Setelah Tanam $(\mathrm{cm})$}

Hasi uji BNT taraf 5\% pada data penelitian diameter umur 60 hari setelah tanam pada perlakuan pupuk organik cair Nasa (V) menunjukkan bahwa perlakuan $\mathrm{v}_{2}, \mathrm{v}_{1}$ dan $\mathrm{v}_{0}$ satu sama lainnya saling berbeda nyata. Diameter batang terbesar terdapat pada perlakuan $\mathrm{v}_{2}$ (konsentrasi pupuk organik cair Nasa $2 \mathrm{ml} / \mathrm{l}$.air), yaitu $0,65 \mathrm{~cm}$, sedangkan diameter batang terkecil terdapat pada perlakuan $\mathrm{v}_{0}$ (tanpa pupuk Nasa), yaitu $0,59 \mathrm{~cm}$.

Hasi uji BNT taraf 5\% pada data penelitian diameter batang umur 60 hari setelah tanam pada perlakuan pupuk kompos (K) menunjukkan bahwa perlakuan $\mathrm{k}_{3}, \mathrm{k}_{2}$ dan $\mathrm{k}_{1}$ satu sama lainnya saling berbeda nyata. Diameter batang terbesar terdapat pada perlakuan $\mathrm{k}_{3}$ (dosis pupuk kompos 45 ton/ha), yaitu $0,64 \mathrm{~cm}$, sedangkan diameter batang terkecil terdapat pada perlakuan $\mathrm{k}_{1}$ (dosis pupuk kompos 15 ton/ha), yaitu $0,59 \mathrm{~cm}$.

Hasil uji BNT taraf $5 \%$ terhadap tinggi bibit umur 60 hari setelah tanam pada interaksi perlakuan pupuk organik cair Nasa dan pupuk kompos (VxK) menunjukkan bahwa perlakuan $\mathrm{V}_{2} \mathrm{k}_{3}$ berbeda nyata dengan perlakuan $\mathrm{v}_{2} \mathrm{k}_{2}$, $\mathrm{v}_{1} \mathrm{k}_{3}, \mathrm{v}_{0} \mathrm{k}_{3}, \mathrm{v}_{1} \mathrm{k}_{2}, \mathrm{v}_{2} \mathrm{k}_{1}, \mathrm{v}_{0} \mathrm{k}_{2}, \mathrm{v}_{1} \mathrm{k}_{1}$ dan $\mathrm{v}_{0} \mathrm{k}_{1}$. Perlakuan $\mathrm{v}_{2} \mathrm{k}_{2}$ dan $\mathrm{v}_{1} \mathrm{k}_{3}$ berbeda nyata 
dengan perlakuan $\mathrm{v}_{0} \mathrm{k}_{3}, \mathrm{v}_{1} \mathrm{k}_{2}, \mathrm{v}_{2} \mathrm{k}_{1}, \mathrm{v}_{0} \mathrm{k}_{2}$, $\mathrm{v}_{1} \mathrm{k}_{1}$ dan $\mathrm{v}_{0} \mathrm{k}_{1}$. Perlakuan $\mathrm{v}_{0} \mathrm{k}_{3}, \mathrm{v}_{1} \mathrm{k}_{2}$ dan $\mathrm{v}_{2} \mathrm{k}_{1}$ tidak berbeda nyata dengan perlakuan $\mathrm{v}_{0} \mathrm{k}_{2}$ dan $\mathrm{v}_{1} \mathrm{k}_{1}$, tetapi berbeda nyata dengan perlakuan $\mathrm{v}_{0} \mathrm{k}_{1}$. Perlakuan $\mathrm{v}_{0} \mathrm{k}_{2}$ dan $\mathrm{v}_{1} \mathrm{k}_{1}$ tidak berbeda nyata dengan perlakuan $\mathrm{v}_{0} \mathrm{k}_{1}$.

\subsection{Diameter Batang Umur 90 Hari Setelah Tanam $(\mathrm{cm})$}

Hasil sidik ragam menunjukkan bahwa perlakuan pupuk organik cair Nasa berpengaruh sangat nyata, perlakuan pupuk kompos berpengaruh nyata, sedangkan interaksinya tidak berpengaruh nyata terhadap diameter batang umur 90 hari setelah tanam.

Hasi uji BNT taraf 5\% pada data penelitian diameter umur 90 hari setelah tanam pada perlakuan pupuk organik cair Nasa (V) menunjukkan bahwa perlakuan $\mathrm{v}_{2}, \mathrm{v}_{1}$ dan $\mathrm{v}_{0}$ satu sama lainnya saling berbeda nyata. Diameter batang terbesar terdapat pada perlakuan $\mathrm{v}_{2}$ (konsentrasi pupuk organik cair Nasa $2 \mathrm{ml} / \mathrm{l}$.air), yaitu $1,02 \mathrm{~cm}$, sedangkan diameter batang terkecil terdapat pada perlakuan $\mathrm{v}_{0}$ (tanpa pupuk Nasa), yaitu $0,91 \mathrm{~cm}$.

Hasi uji BNT taraf 5\% pada data penelitian diameter batang umur 90 hari setelah tanam pada perlakuan pupuk kompos (K) menunjukkan bahwa perlakuan $\mathrm{k}_{3}$ berbeda nyata dengan perlakuan $\mathrm{k}_{2}$ dan $\mathrm{k}_{1}$. Perlakuan $\mathrm{k}_{2}$ tidak berbeda nyata dengan perlakuan $\mathrm{k}_{1}$. Diameter batang terbesar terdapat pada perlakuan $\mathrm{k}_{3}$ (dosis pupuk kompos 45 ton/ha), yaitu $0,99 \mathrm{~cm}$, sedangkan diameter paling kecil terdapat pada perlakuan $\mathrm{k}_{1}$ (dosis pupuk kompos 15 ton/ha), yaitu $0,93 \mathrm{~cm}$.

Pengaruh Pupuk Organik Cair Nasa Terhadap Pertumbuhan Bibit Jeruk Manis (Citrus aurantium). Perlakuan pupuk organik cair Nasa berpengaruh nyata terhadap tinggi bibit umur 60 hari setelah tanam, jumlah daun umur 30 hari dan 60 hari setelah tanam dan diameter batang umur 30 hari dan 60 hari setelah tanam.

Hasil sidik ragam menunjukkan bahwa perlakuan pupuk organik cair Nasa berpengaruh nyata dan sangat nyata secara umum terhadap tinggi bibit, jumlah daun dan diameter batang pada umur 30 hari, umur 60 hari dan umur 90 hari setelah tanam. Secara berurutan bibit tertinggi terdapat pada perlakuan $\mathrm{v}_{2}$ (konsentrasi pupuk organik cair Nasa 2 $\mathrm{ml} / \mathrm{l}$.air), yaitu $14,11 \mathrm{~cm}, 23,80 \mathrm{~cm}$ dan $31,87 \mathrm{~cm}$. Perlakuan pupuk organik cair Nasa dengan konsentrasi 2 ml/l.air menghasilkan bibit yang lebih tinggi, jumlah daun yang lebih banyak dan diameter batang yang lebih besar, bila dibandingkan dengan perlakuan lainnya, baik perlakuan $\mathrm{v}_{1}$ (konsentrasi pupuk organik cair nasa 1 ml/l.air) maupun perlakuan $\mathrm{v}_{0}$ (tanpa pupuk organik cair Nasa). Keadaan ini disebabkan bahwa semakin tinggi konsentrasi pupuk organik cair Nasa yang diberikan maka cenderung meningkatkan tinggi tanaman, jumlah daun dan diameter batang. Hal ini diduga terkait dengan semakin meningkatnya unsur hara yang terkandung dalam pupuk organik cair Nasa yang dapat diserap oleh tanaman melalui stomata, terutama adanya peranan unsur nitrogen $(\mathrm{N})$ dalam pertumbuahn vegetatif tanaman. Sebagaimana dikemukakan oleh Sutedjo (2009) yang menyatakan bahwa unsur nitrogen berperan untuk merangsang pertumbuhan vegetatif tanaman seperti tinggi, jumlah daun dan luas daun.

Perlakuan pupuk organik cair Nasa sangat berpengaruh nyata pada semua parameter penelitian, karena pupuk organik cair Nasa mengandung unsur hara yang lengkap, yaitu unsur hara makro dan mikro juga mengandung zat pengatur tumbuh seperti asam asetat yang memacu tanaman tumbuh lebih baik, POC Nasa juga mmeperbaiki kesubuan tanah, aktivitas mikroorganisme tanah, 
sehingga pemupukan menjadi lebih efektif dan ekonomis. POC Nasa juga dapat mengurangi tingkat serangan hama. POC Nasa mengandung unsur hara makro maupun unsur mikro seperti : $\mathrm{N}$ $0.12 \%, \mathrm{P} 2 \mathrm{O} 50.03 \%, \mathrm{~K} 0.31 \%$, Ca 60.40 ppm, S $0.12 \%, \mathrm{Mg} 16.88$ ppm, $\mathrm{Cl}$ $0.29 \%$, Mn 2.46 ppm, Fe 12.89 ppm, Cu < 0.03 ppm, Zn 4.71 ppm, Na $0.15 \%$, B 60.84 ppm, Si $0.01 \%$, Co < 0.05 ppm, Al 6.38 ppm (PT Natural Nusantara, 2005).

Pengaruh Pupuk Kompos Terhadap Pertumbuhan Bibit Jeruk Manis (Citrus aurantium). Perlakuan pupuk kompos berpengaruh nyata terhadap diameter batang umur 60 hari dan 90 hari setelah tanam. Berpengaruh sangat nyata terhadap tinggi bibit umur 30 hari, umur 60 hari dan umur 90 hari setelah tanam, jumlah daun umur 30 hari, umur 60 hari dan umur 90 hari setelah tanam, serta diameter batang umur 30 hari setelah tanam.

Pemberian pupuk kompos pada pertumbuhan bibit jeruk untuk semua parameter berpengaruh sangat nyata, dan perlakuan yang paling baik untuk semua parameter baik untuk tinggi tanaman, jumlah daun dan diameter batang terdapat pada perlakuan $\mathrm{k}_{3}$ (dosis pupuk kompos 45 ton/ha), hal tersebut dapat dilihat pada data penelitian yang terdapat pada Tabel 1 (Tabel Rekapitulasi), bila dibandingkan dengan perlakuan $\mathrm{k}_{2}$ (dosis pupuk kompos 30 ton/ha) dan perlakuan $\mathrm{k}_{1}$ (dosis pupuk kompos 15 ton/ha).

Pupuk kompos memiliki keunggulan-keunggulan seperti : mampu memperbaiki struktur tanah, memiliki kandungan unsur hara makro dan mikro yang lengkap, ramah lingkungan, murah dan mudah di dapat atau dibuat sendiri, mampu menyerap dan menampung air, dan mampu memperbaiki aktivitas mikrobia tanah. Adapun kandungan unsur hara makro pada pupuk kompos yaitu : unsur Nirogen 1,69 \%, Fosfor 0,34\%, Kalium 2,81 \%, Calsium 4,20\%,
Magnesium 1,10 \% dan unsur hara mikro yaitu : Mangan 684 ppm dan Zn 144 ppm (Agro Media Pustaka, 2008). Dengan keunggulan dan kandungan unsur hara yang dimiliki oleh pupuk kompos tersebut, maka pertumbuhan bibit jeruk menjadi lebih baik, karena media tanam menjadi lebih baik bagi perkembangan akar dan tersedia unsur hara bagi pertumbuhannya.

Pengaruh Interaksi Perlakuan Pupuk Organik Cair Nasa dan Pupuk Kompos Terhadap Pertumbuhan Bibit Jeruk Manis (Citrus aurantium). Hasil sidik ragam menunjukkan bahwa interaksi perlakuan antara perlakuan pupuk Nasa dan pupuk kompos tidak berpengaruh nyata terhadap tinggi bibit umur 30 hari dan 60 hari setelah tanam, jumlah daun umur 30 hari, umur 60 hari dan umur 90 hari setelah tanam, diameter batang umur 30 hari dan umur 90 hari setelah tanam. Berpengaruh nyata terhadap diameter batang umur 60 hari setelah tanam. Berpengaruh sangat nyata terhadap diameter batang umur 60 hari setelah tanam.

Adanya pengaruh interaksi yang berbeda sangat nyata atau berbeda tidak nyata tersebut disebabkan karena selama proses pertumbuhan bibit jeruk tersebut terdapat tahapan pertumbuhan yang intensitasnya berbeda-beda dan juga dengan semakin meningkatnya umur bibit tersebut, sehingga membutuhkan unsur hara yang berbeda pula. Seperti dinyatakan oleh Sutedjo dan Kartasapoetra (2002), bahwa kebutuhan tanaman akan bermacam-macam unsur hara (pupuk) adalah tidaklah sama, membutuhkan waktu yang berbeda dan tidak sama banyaknya. Sepanjang pertumbuhannya ada saat dimana tanaman memerlukan unsur hara lebih banyak, agar pertumbuhannya berlangsung dengan baik.

Data hasil penelitian yang disajikan pada Tabel 1 (Rekapitulasi) secara umum 
menunjukkan bahwa kombinasi perlakuan konsentrasi pupuk organik cair Nasa 2 ml/l.air dengan dosis pupuk kompos 45 ton/ha $\left(\mathrm{v}_{2} \mathrm{k}_{3}\right)$ menghasilkan pertumbuhan bibit jeruk manis yang lebih baik dibandingkan dengan interaksi perlakuan lainnya. Hal ini menunjukkan bahwa antara kedua pupuk tersebut (pupuk organik cair Nasa dan pupuk kompos) dapat saling melengkapi (saling mendukung) untuk memenuhi kebutuhan unsur hara bibit jeruk manis tersebut, yaitu pupuk organik cair Nasa mensuplai unsur hara yang diberikan melalui daun dan pupuk kompos yang diberikan ke dalam media tanam dan berperan penting dalam memperbaiki sifat fisik, kimia dan biologis tanah. Seperti dikemukakan oleh Musnamar (2003), bahwa pupuk organik dapat memperbaiki sifat fisik, kimia dan biologi tanah serta dapat mengurangi pencucian unsur hara yang biasa terjadi terhadap pupuk kimia (pupuk anorganik).

\section{KESIMPULAN}

Kesimpulan dari hasil penelitian adalah sebagai berikut: Perlakuan pupuk organik cair Nasa tidak berpengaruh nyata terhadap jumlah daun umur 90 hari setelah tanam. Berpengaruh nyata terhadap tinggi bibit umur 60 hari setelah tanam, jumlah daun umur 30 hari dan 60 hari setelah tanam dan diameter batang umur 30 hari dan 60 hari setelah tanam.

Perlakuan pupuk kompos berpengaruh nyata terhadap diameter batang umur 60 hari dan 90 hari setelah tanam. Berpengaruh sangat nyata terhadap tinggi bibit umur 30 hari, umur 60 hari dan umur 90 hari setelaha tanam, jumlah daun umur 30 hari, umur 60 hari dan umur 90 hari setelah tanam, serta diameter batang umur 30 hari setelah tanam.

Interaksi perlakuan antara perlakuan pupuk organik cair Nasa dan pupuk kompos tidak berpengaruh nyata terhadap tinggi bibit umur 30 hari dan 60 hari setelah tanam, jumlah daun umur 30 hari, umur 60 hari dan umur 90 hari setelah tanam, diameter batang umur 30 hari dan umur 90 hari setelah tanam. Berpengaruh nyata terhadap diameter batang umur 60 hari setelah tanam. Berpengaruh sangat nyata terhadap diameter batang umur 60 hari setelah tanam.

\section{DAFTAR PUSTAKA}

Agro Media Pustaka. (2008). Cara Praktis Membuat Kompos. Jakarta.

Endarto, O dan E. Martini. (2016). Pedoman Budidaya Jeruk Sehat. Worl Agroforestry Centre dan AGFOR Sulawesi. Bogor.

Kemas Ali Hanafiah. (2006). Dasardasar Statistika. Jakarta: PT Raya Grafindo Persada.

Sutedjo, M.M. (2009). Pupuk dan Cara Pemupukan. Jakarta: Rineka Cipta.

Musnamar, E.I. (2003). Pupuk Organik Padat. Jakarta: Penebar SwadayaJakarta.

PT Natural Nusantara. (2005). POC NASA. Indonesia.

Sutedjo, M. M. dan A. G. Kartasapoetra. (2002). Pengantar Ilmu Tanah. Jakarta: Rineka Cipta.

Steel, R.G.D., dan Torrie,J.H. (1994). Prinsip dan Prosedur Statistika Suatu Pendekatan Biometik. Jakarta: Penerbit PT. Gramedia Pustaka Utama.

Wirakusumah. (1999). Teknik Budidaya Tanaman Jeruk Beserta Pemeliharaanya. Jakarta: Penebar Swadaya. 